\title{
PUBLIC RELATIONS IN TURKEY FROM WOMEN'S PERSPECTIVE
}

\author{
Murat SEYFİ \\ Gaziosmanpaşa University, Turkey \\ http://orcid.org/0000-0002-7188-235X \\ Seyfi.murat@gop.edu.tr \\ Deniz GÜVEN \\ Marmara University \\ denizguvenn@gmail.com \\ Merve ÇERÇİ \\ Marmara University
}

\begin{abstract}
When foreign capital entered the country and new government policies were developed in this area in the end of 1960s, studies on public relations increased in Turkey. In the historical process to the present, many women have had an active part in development of the discipline. People who entered the profession between 1960s and 1990s realised the importance of public relations in its early period, and these people conducted miscellaneous studies. People who preferred this profession in 1990s and worked in the sector, were affected from socio-economic factors and education policies, and the discipline acquired a new dimension. With developments in mass media in 2000s and communication technologies' becoming important parts of our lives, the discipline entered into a new process of evolution. This study aims to analyse the topic by centering woman perspective of the development of the discipline. Since the representatives both from the old and young generation are brought together within the context of the study, it differs from other studies and brings new stratas to the topic. In this study in which in-depth interview method was used, it is determined that women make an effect of catalyst in the development of public relations and that they formed an important basis for the development of the process.
\end{abstract}

Keywords: History of Public Relations in Turkey, Public Relations, Perspective of Woman

\section{KADIN PERSPEKTIFIINDEN TÜRKIYY'DE HALKLA İLISSKILLER}

\section{ÖZ}

Türkiye'de halkla ilişkiler çalışmaları 1960'lı yılların sonlarında yabancı sermayenin ülkeye gelmesi ve bu alanda yeni devlet politikalarının geliştirilmesi ile artmıştır.Günümüze kadar geçen tarihsel süreçte birçok kadın bu disiplinin gelişmesinde aktif rol almıştır. Mesleğe 1960-1990 yılları arasında giren kişiler halkla ilişkilerin önemini erken dönemde farketmiş ve bu disiplinle çok yönlü çalışmalar yapmış kişilerdir. 1990'lı yıllar ile birlikte mesleği seçen ve sektörde çalışan kişiler sosyo-ekonomik faktörlerden ve eğitim politikalarından etkilenmiş kişilerden oluşmuş ve disiplin yeni bir boyut kazanmıştır. 2000'li yıllarda ki kitle iletişim araçlarındaki gelişmeler ve yeni iletişim teknolojilerinin hayatımızın önemli bir parçası haline gelmesi ile disiplin yeni bir evrim geçirme sürecine girmiştir. $\mathrm{Bu}$ çalışma halkla ilişkiler disiplinin gelişiminde kadın perspeftifini merkeze alarak konunun analiz edilmesini amaçlamaktadır. Araştırma kapsamında hem yeni nesil hem de eski nesil den temsilcilerin bir araya getirilmesinden dolayı diğer çalışmalardan ayrılıyor ve konuya yeni katmanlar kazandırıyor. Derinlemesine görüşme yöntemi kullanılarak yapılan bu çalışmada; kadınların halkla ilişkilerin gelişiminde katalizör etki yaptığı ve disiplinin gelişiminde önemli bir temel oluşturdukları tespit edilmiştir.

Anahtar Kelimeler:Türkiye'de Halkla İlişkiler Tarihi, Halkla İlişkiler, Kadın Perspektifi 


\section{INTRODUCTION}

Throughout the history, public relations has been an ever-changing and ever-growing discipline. The most basic reason for this is that the discipline is affected by cultural, political, technological, and sociological developments and changes. Therefore, studies focusing on the historical development of public relations analyse not only this discipline but also many historical developments in the world. Thus, interdisciplinary studies are gradually becoming more important in these kind of studies.

Throughout its history, public relations has been a profession favoured by women, and in which they are employed. Therefore, there have been many studies regarding women's position in the sector of public relations in various areas of the world. It has been determined that women in the sector who are from different countries suffer from gender discrimination and thus, they suffer from mobbing in terms of money, status and so forth. This issue is totally different in Turkey's history. It can be seen that there have been collective works of men and women when the development of public relations as a profession in Turkey is analysed. In the course of time, it is seen that the number of women executives in the sector is even more than men.

In this study, a situational analysis is made by profound interviews with academicians, sector representatives and workers who live in different cities of Turkey. In order to acquire different perspectives during data collection, both the individuals who are in this sector for more than 30 years and public relations experts from the rising generation who have entered this sector in the last 10 years are included in the sample. In consideration of this data, effects of women are evaluated in the historical development process of the sector of public relations in Turkey.

\section{Studies on the history of public relations}

There are many studies about the history of public relations in the international literature. The basic reason for this is that it has a past whose beginning is undetermined. Public relations has existed since people's efforts to gain other people's trust existed. Concepts have been developed only to name this. Social, cultural, societal and political differences came into prominence in the development processes of these concepts. Accordingly, different processes of public relations that are developed in different societies put forward the importance of its own historical development (Faulstich, 1992: 41). Criticisms about dominant history of public relations narrative have caused the rise of new tendencies in historiography of public relations. The most important of these tendencies is each country's effort to create its unique public relations history by evaluating its public relations practices which are created according to its own socio-economic and cultural factors (Şanl1, 2015: 135).

Conceptualization of public relations arose through the studies which started in 1900s in the USA. It is inevitable for different definitions of public relations to include different historical narratives. In consideration of the data that was acquired from 65 experts in 1970s, it was determined that 472 definitions of public relations had been made (Harlow, 1977). In order for the concepts to become more controllable, the institutions of IPRA (International Public Relations Associations), CERP (CONFEDERATION DES Relations Publiques), DPGR (Deutsche Public Relations Gesellschaft), PRVA (Public Relations Verband Austria) and SPRG (Schweizerische Public Relations Gesellschaft) cooperated to make definitions in the late 1970s. This provided the appearance of the concept's general structure, and offered perspectives for new tendencies (Ronnenberg, 1992: 32). It is seen that modern practices of public relations that started in 1900s in the USA are at the base of all these studies about historical process analysing. In particular, public relations models that were put forth by prominent figures like Bernays and Lee affected historical process. For example, Bernays tried to explain the subject by linking public relations history with American history. According to Bernays, historical process of America's social and political structure was related to historical process of development of public relations. The first period of public relations and civil war in America are in the same period of time, and the idea that the people could be deceived dominated this period. In the second period, public relations and government policies developed together, and this turned into "people should be informed". In the third period, public relations was seen as a professional occupation. In this period public relations was related to the concepts of public opinion, power, and influence. The fourth period is the period from Great Depression to the beginning of the World War II. 
The historical development of public relations, which was affected by American schools, started to be shaken with the studies that came from comprehensive analysis of the history of public relations in 2000 s, and with the critical tendencies aimed at the dominant paradigm of public relations. In criticisms, it was stated that public relations models were grounded on the practices of public relations. In the studies, the importance of practices that did not follow American school was remarked, and multilateral practices of public relations beyond journalism and announcement were also remarked (Gower, 2008: 309). This caused researchers to find new tendencies in historiography of public relations (Yamanoğlu et al, 2013: 23). Lamme stated that historiography of public relations could be extended with the usage of different research methods from researchers who come from interdisciplinary studies, and he made suggestions about this (Lamme, 2009: 156-159).

\section{History of public relations in Turkey and women's position}

The Ottoman Empire is the basis of public relations in Turkey. There were practices of public relations which were very different from today's public relations models, and were related to the empire's domestic dynamics. The Sultan had a responsibility towards only the God. However, the God wanted him to treat his people well, fairly and justly by way of the Qur'an. Therefore, the Qur'an had been an important guiding spirit in the relationship between the government and the people. Even though it was possible for people to complain about institutions and other people to central bureaucracy, the relationship between the government and the people generally was unilateral and asymmetrical within this system. Since women were not in the executive positions in the Ottoman Empire, their effect in this communication chain was low. Development of public relations in the Ottoman Empire was parallel to socio-cultural developments and changes. In the early times of the empire, the communication process which was based on face to face meetings started to be performed through codes of laws later on. In particular, mosques had a vital role in practices of public relations when religious elements appeared mostly (Kazanc1, 2006: 6-9). In the Ottoman Empire, the appearance of women in the area of public relations was based on the years when the government is vulnerable. Rule of the empire passed to the mothers of the sultans when they started to come to the throne at an early age. Though they did not possess the official right to rule, the rule of the empire passed to women unofficially. In these periods, even if it seemed that there was no difference in terms of practice, mothers of the sultans caused the creation of a new dialogue between the government and the people through their social responsibility activities. In particular, Kosem Sultan made some charities and developed dialogues with people, which contributed to the development of public relations with a symmetrical and bilateral model by women (Keating, 2007; Küpeli, 2015). Generally, works of public relations in Ottoman Empire were unsystematic and were conducted under the supervision of government and shaykh al-islams.

The establishment of the Republic of Turkey and systematization of public relations around the world were in the same period. This allowed the country to conduct public relations more professionally. Practices of public relations in the establishment years of the Republic of Turkey appeared in the form of presentation of novelties and alterations which aimed to build a national consciousness to Anatolian people (Erdoğan, 2008: 132). Mustafa Kemal Atatürk, the founder of the Republic of Turkey, made Anatolian tours, organized sample events and meetings, and made speeches in order for reforms to be presented and announced to the people, be embraced by the people, and be a part of the daily life. $\mathrm{He}$ often made use of these tours to make these reforms be embraced by the people, and these tours had an important role in receiving the approval of the people (İşler and Keloglu, 2010: 169-171). Atatürk used a lot of images of women in this period. Women came into prominence in entertainment and government organizations, and this was the first time that images of women came into prominence in communicating with the people. In particular, the speeches made by the wife of Atatürk about women had an important role in the works of public relations. It is seen that public relations was gradually becoming more important when the practices of public relations of politicians and government representatives of those years are analysed. Roosevelt, the president of the United States of America, made important public relations practices in 1933 by giving speeches on radio, called the Fireside Chats. While Roosevelt made his presidential campaign and talked about subjective issues in his speeches, Atatürk focused on the social changes with his works on the topic. Since these attempts at 
social change included women, the images of women and components of this image were often used in the communication works in this period (Erdoğan, 2008: 140-141).

Generally, the three most important historical processes are considered when evaluating the history of public relations in Turkey: the Single party period (1920-1946), the Multi-party period (1946-1960), and the 1961-1980 emergence of public relations (Bıçakçı\&Hürmeriç, 2013: 91-100). Works that were done by Atatürk are considered to be in the single party period. The relationship between the government and the people started to be questioned when multi-party period started in 1946. From then on, the politicians stated that the main aim of the regime of republic was to protect the benefits of the people, and they gave speeches saying that government officers should treat people well and should develop their relationship with them (Acar, 1994: 84). Though liberal policies were followed by the governments in this period, due to the fact that the private sector lacked institutionalisation, practices of public relations were not completely implemented (Erdoğan, 2008: 157). Nermin Abadan Unat, one of the first woman academicians in the area of public relations, wrote a paper entitled "Halkla Münasebet" in 1955, which is the first Turkish text about public relations. Prof. Dr. Nermin Abadan Unat made substantial contributions to the institutionalisation of the education of public relations, and she conducted an important study for this area to develop by drawing attention to the importance of the area in the practices of both the public and the private sector (Yamanoğlu and the others, 2013: 36).

Examples of public relations started to be seen in the public sector in the early 1960s. Ministry of Foreign Affairs and General Staff worked to make better and to direct public relations. The first modern public relations works started when the representation branch was included in the coordination department of the State Planning Organization, which was found in 1961. Through the "MEHTAP" project, which was organised by this branch, asserted that "It is a must to maintain a close relationship with the people in the works which are in each level of state organisations, and in decision making." (Okay\&Okay, 2014: 25). Women started to participate actively in the practices of public relations in this period. Birten Gökyay took charge as publication and advertising expert in MPM between 1968 and 1972, and she established the first unit of public relations which is the unit of public relations of MPM. MPM brought together the representatives of the public and the private sector in a common platform, and thus; it had an effect on public relations' becoming a widespread sector and being embraced in Turkey. Besides, it became a role model for women to take part actively in the sector. In the same years (1969), Betül Mardin, Ayşegül Dora and others played important parts in organising first congress of the World Chamber of Commerce in Turkey and in establishing advertisement companies. Public relations works done by Betül Mardin created a worldwide effect, and she took the chair in IPRA in 1995 (Yamanoğlu, 2013: 39-40). The introduction of public relations to private institutions was possible in 1970s due to economic developments in Turkey. Multinational companies, with the lead of oil companies, attached importance to public relations. After multinational companies, major Turkish holdings like Koç, Eczacıbaşı and Sabancı started to tend to the area, and thus; the development of public relations in the private sector gained speed (Asna, 1988: 29).

\section{Women in the area of public relations}

The general name for social movements which aim to make better the social standing of women can be called feminism. There have been many studies about feminization of public relations in the recent years. These studies referred to various topics such as status, money, academic success, how the women working in the area of public relations were perceived from the others and etc. (Beasley\&Thesus, 1998; $\quad$ Broom, 1982; Broom\&Dozier, 1986; Ciner, 2003; Childers, 1986; Dozier, chapo\&Sullivan, 1983; Scrimger, 1985; Theus, 1985; Tany1ldiz; 2011, Turan, 2014; Turk, 1986; Yıldırım\&Metin, 2011). Generally, dominant methodological paradigms in social sciences seek a way to predict and control human behaviour; however, feminist theory, in addition to these, focuses on changing the social life. Therefore, there are many studies aimed at asserting feminist theories made by Bernard (1981), Harding (1986), Johnson (1985), Grunig (2000), (Hon, 1995). In order for this occupation to develop, it is vital to assert feminist values in public relations. It is seen that $70-80 \%$ of the students studying public relations are women. Therefore, assertion of feminist values should start during education years (Grunig and the others, 2000: 62-64). Farmer and Waugh (1999) 
determined that there are considerable differences between the attitudes of both genders in consequence of their studies aimed to determine the perceptions of both male and female students towards the occupation of public relations. Male students stated that they were expecting higher salaries, quicker promotion to executive positions than their female counterparts when they started their career. Another conclusion is that the female students believed that they should postpone their plans about starting a family and having kids for the sake of their career progress. Another important finding is that the male students agreed that there were not any problems about gender discrimination in the area of public relations. However, the same students did not agree with the idea that women public relations executives are as effective as men. This distrust towards women executives indicates the existence of gender discrimination (Farmer\&Waugh, 1999).

It is seen that the occupation of public relations become feminised and mostly professed by women when the studies which are conducted about the women in the area of public relations are observed (Öksüz \& Görpe, 2014: 127). According to research conducted in 42 countries by European Communication Monitor in 2014, it was revealed that the occupation of communication is feminised in Europe (European Communication Monitor 2014: 118). Women made up the 12\% of the members of Industry of Public Relations (IPR) in England in 1975 and 20.8\% in 1987. During 1970s and 1980s, the number of woman practitioners of public relations rose from about 400 to at least 4000 . Today, about two thirds of 61.600 English practitioners of public relations are women (Yaxley, 2013: 156157). Considering Arabian world, in many Arabian countries the rate of women working in the area of public relations is lower than the countries in the other parts of the world, especially than the western countries. In many Arabian countries, the rate of woman practitioners of public relations is updated and is not certain (Al-Jenaibi, 2011:36).

Like Europe, the sector is also becoming feminised in America. Throughout history, the number of women working in the area of public relations has risen. According to the data of the year of 2013 of the US Bureau of Labour Statistics, 63\% of public relations experts were women. According to the data of the year of 2010, $73 \%$ of 21.000 members of the Public Relations Society of America were women (Makovsky, 2013). According to the research conducted by the journal of "Marketing Türkiye" (2005), 69\% of professionals of public relations are women in Turkey. $76 \%$ of the members of the Public Relations Society of Turkey (TÜHID) are women. Since the public and the private sector have different practices of public relations and viewpoints about it, the position of the women varies greatly. While public relations is perceived as "a way and a method of communicating with press" in the public sector, it is perceived as "a method of selling the products of the organization and improving the profit" by someone who is attendant in the private sector (Uysal Sezer, 1988: 197). This causes the differentiation of the position of women in the public and the private sector in Turkey. It is seen that both the men and the women worked in executive and founder positions in this sector, when the years of 1960-80, which are the years of development of public relations in Turkey, are analysed. Many women like Betül Mardin, Nermin Unat crossed the borders and continued their activities worldwide. It has been determined that most of them studied in American colleges like Robert College and came from educated families. Therefore, these people, who laid the foundation of this sector in Turkey, facilitated the rise and the development of the sector in Turkey by putting together both the West's and Turkey's cultural factors. This provided the change of feminist values of public relations in Turkey into a multi-layered structure.

Academic studies made throughout the history in Europe and America suggest that there have been problems about being female in the sector of public relations. However, this issue is not that clear in the studies which are made in Turkey. According to a research conducted by Tanyıldiz1 (2011), 79.2\% of the women working in this sector in Turkey stated that they did not experienced any kind of discrimination just because they are woman. Öksüz and Körpe (2014) determined that the women in the area of public relations in Turkey are not facing huge problems while being installed in executive positions. Through a field research, it is determined that women were even in the leading positions in the historical process of public relations in Turkey. While the men were leading the development of public relations in the West, women were always at the forefront of this development in Turkey. 


\section{METHOD}

\section{Methodology of the Study and Sample}

It can be seen that literature review and in-depth interview techniques were often used when methodologies of the studies about the History of Public Relations are analysed. It is seen that content analyses of publications, especially which remained secret in the past (Yavuz, 2008), or books and similar documents that were free to use in academia or in libraries were made through literature review technique in Turkey (Şanl1, 2015). Thanks to these analyses, researchers can obtain both quantitative and qualitative data. On the other hand, in the methodologies of studies in which in-depth interviews are made, data obtained from interviews with generally the founders of this field (H1zal et al, 2014) or with people from the rising generation who contribute to the development of this field (Öksüz\&Görpe, 2014) are in question. In in-depth interviewing, a hypothesis cannot be analysed. In these kind of studies, researchers reach to primary source by revealing stories and experiences of people. This is vital for historical research (Seidman, 2013: 7-9).

Regarding these research methodologies, a literature review was made primarily by analysing sources and documents about the topic. Subsequently, semi-structured interview technique was used. A semistructured interview is " $A$ data acquisition method that is commonly used in qualitative research as an interviewing method, and in which researchers can ask formerly-prepared or new questions on the topic that arise during interviewing." In semi-structured interviews, interviewing is not made only with one person; it can also be made with more than one person according to the course of the research. Through this method, researcher can deepen his/her research by focusing on knowledge and experiences of the person whom he/she interviews. (Güler et al, 2013).

Within this context, for the research to reach its aim a sample was created which consists of academicians, practitioners and representatives of occupational organizations. While determining the sample, a group of 11 people that can represent female perspective and consists of both the old generation that have been in this sector for more than 30 years and female experts from the rising generation who have entered this sector in the last 10 years were chosen, and in-depth interviews were made with them. Since interviewees who are defined as the young generation had no personal history, and since some participants weren't willing to share their identities, identities of all the participants were kept secret. Questions within the context of this study were prepared based on the literature review made by the researcher. Prepared questions were submitted to experts, and in consequence of their evaluation whether the questions were clear and expressed understandably was speculated. In consequence of these speculations, questions were readjusted in accordance with directives from the experts, and were finalised. The group of 11 people, who makes up the sample of the study, live in different parts of Turkey. For this reason, interviews were made face to face or via skype and phone. A coding system was developed with respect to the similarity relation of obtained replies within the context of this study. During the coding process, tables were created separately for each question, and coding of them were made accordingly. Thus, all replies to same question were analysed in the same table. Main themes were determined and replies were categorised by taking the data obtained within the context of this study into consideration. Within the framework of acquired qualitative data, the position of women was argued in the historical process of public relations in Turkey. The reason for the number of sample's being limited is that the number of people who have more than 30 years of experience in the sector is limited. Since the balance between participants are considered in this sample which brings old and young generation together, the number of the sample is 11 .

Within this context, research questions are as follows:

RQ1: What is the position of women in the sector of public relations in Turkey?

RQ2: What problems do women face within the sector?

RQ3: From which different aspects does the discipline of public relations are evaluated between old and young generation working in the sector?

RQ4: In topics like ethics, academia, entering the profession, what kind of developments observed in the historical process in Turkey? 


\section{FINDINGS}

Findings of the study is gathered with in-depth interview method. Regarding the plentifulness and controllability of the data acquired, they are categorised under 6 heads which are women's position in the sector of public relations in Turkey, process of entering the profession, experiences, being a woman in the sector, ethics and public relations, and academia and public relations.

\section{Position of Women in the Sector of Public Relations in Turkey}

There have been many studies aimed to determine the position of women in the sector of public relations from the historical perspective. When these studies are examined, it is seen that the topic has been researched for a long time both with qualitative and quantitative methods (Bernard, 1981; Broom, 1982). However, these kind of studies in Turkey are quite recent. Within this context, developing hypotheses regarding position of women within the sector is highly difficult. Within this framework, the focus is sectoral (both academic and professional) experiences in order to determine the position of women in the sector of public relations in Turkey. Similarly, there is a study conducted by Aktaş (2013) which focuses on experiences.

When the studies conducted in America which aim to determine the position of women in the sector of public relations (Beasley\&Thesus, 1998; Broom, 1982), it can be seen that the focus is factors regarding gender. In Turkey, this is different. Someone who has been in this sector for more than 30 years refers to two main problems. The first one is problems related to being a woman and the second problem is that the profession is not understood. In particular, there is a huge difference between perception levels of old generation and young generation. Opinions of people who have in this sector for more than 30 years and participated in the study are as follows: "When I argue this topic as an academician and sector employee for more than 30 years, I think there are two main problems. First one is about the occupation of public relations beyond being a woman; namely, the occupation is not being performed as it should be, since it is still not understood completely. This is causing the basis of the occupation not to be structured well. On the other hand, the entity of women in this unperceived occupation is highly interesting, since they are facing with both the problems of unperceived occupation and problems about being woman..." Maybe the basic problems about positioning women in the sector of public relations were the problems faced in the development process of public relations. Because socio-economic level of the country and education policies affected this process so much (Kazanc1, 1997). Representatives of older generation who participated in the study refer to similar problems: "I want to ponder on this question from a different perspective. Women who are the first representatives of this occupation and women from the rising generation... The first representatives were children of educated families and all of them had abroad experience. It was very difficult to find qualified employee that knew foreign language in the 1960s and 70s in Turkey. They were distinctive and highly sought... They chose the occupation of public relations with all these qualities... In other words, there were willing commitment and tendency in the formation process of the occupation. However, this changed in the course of time. The most major reason for this was the education system and socio-economic structure in Turkey. Due to university entrance exam, the youth was not able to study the fields that they had wanted. This changed the developmental line of the occupation... In addition, socio-economic concerns had always been an element of oppression for the ones who were professing public relations..."

In the creation process of public relations in Turkey, there have been many woman leaders. However, this does not necessarily mean that the sector was led by women. In Turkey, there was an important co-operation regardless of gender. Actually, this co-operation has always placed women in a powerful position (Tanyıldız1, 2011)... "I do not want to approach with a sexist point of view but greatest leaders of this sector in our country were women... Of course there were great leaders like Alaaddin Asna but women were always there..." Asna, one of the most important representatives of the sector in Turkey, established A\&B Public Relations company with partnership of Betül Mardin, who is a woman pioneer of the sector (Eser, 1989).

On the other hand, when the topic is analysed from the perspective of the people who newly-entered the sector, a new dimension appears. Now, globalisation and developments in communication 
technologies play an important role in forming process of the sector rather than factors about being a woman or about the profession of public relations: "I have been working in this sector for about 3 years. Actually I did not get my bachelor's degree from public relations but I improved myself by attending educational seminars within this area. This sector which was focused on marketing and advertising for me when I first entered this sector have changed this focus gradually. It is a sector in which there are communication wars... I am not sure that being a man or a woman matters that much but I think women's emotional structure is more suitable for this job. In addition, persuasion was primarily produced through face to face and advertising works earlier but now communication technologies started to recreate the concept of persuasion. For this reason, I think the ability to accommodate oneself to communication technologies have become more important than the concept of gender..."

\section{Process of Entering the Occupation}

Entering the sector of public relations is categorised under two heads in Turkey. The first one is people who are educated abroad and choose this profession voluntarily like Betül Mardin and Alaaddin Asna, who are the first representatives of the profession (Aktaş et al, 2013). In the years following Betül Mardin and Alaaddin Asna, in 1980s and 90s, a similar tendency kept going. Opinions of the people who participated in the study; "I planned academic life when I just entered the university as a student. As for Public Relations, its elbow room's and coverage area's being wide due to its feature of acting proactive were the most interesting dimensions of it for me. It was new in the academic field. I remember tending to and wondering about it for these reasons, but of course there must be other elements playing their part. For example, I think a little need of the faculty in this area also had an effect..." (Interviewee 3). "I started my education in 1976. Its name was Journalism Collage when I started. I was just a 17 year-old kid. I remember talking to former graduates and I really liked the syllabus because the education was so much different from the one we have today, I assure you. I studied pleasurably, since the education that we had in these days, the journalism education, was similar to Liberal Arts Education under the name of Public Relations Collage in USA, which was very popular. If you ask me how I liken them, it is such a department that one can continue to study in which field one wants to study. An education that qualifies one basically. Maybe if I had the opportunity now, I would study once more. There were manager and deputy manager in our faculty. Actually, I do not remember professors on the permanent staff, professors from other universities, from Istanbul University, would come. For example, we studied French and English Literature. I guess we studied 7 or 8 law subjects and other subjects like economics, statistics, cultural history and political history. If we are to leave the details behind, what led me? I was led by this mosaic to communication. Qualifying with basic knowledge excited me about this occupation. I decided that I was just like I wanted. I felt that it could not restrict me but I could advance on it. Thus, I initially made my career decision." (Interviewee 9) Within this process, these people who laid the foundation of the sector started to feel worried about the new generation following them: "...The process of entering the occupation has changed so much in Turkey in the course of time... The understanding that there opened a new department so we employ the people we know dominated the 1970s... It is highly interesting that the executives looked upon this sector as a job that could be done by everyone, since they did not know what this occupation exactly was... This started to change with the 80 s and $90 \mathrm{~s}$. People who were presentable, had smooth diction and social skills were started to be chosen, and this caused the occupation to be seen as an occupation for women for a long time... However, the process have changed a little with the developments in communication technologies in the recent years. Now, being presentable or having a smooth diction is not enough, it is also necessary to use communication technologies effectively... This is altering the perception of women in the sector of public relations in the process... and public relations is becoming an occupation in which quality is questioned rather than gender..." (Interviewee 5)

Entering the sector of public relations in Turkey changed in 2000s. From then on, economic and sociocultural factors appeared. Since then, expectation of professionals of public relations from graduates of faculty of communication acquired a new dimension (Gürel, 2006: 364). According to participants of the study from the young generation: "A university degree is certainly not enough to find a good job in 
Turkey... I had no hope about having a job in this sector though I was a graduate of public relations... but I am pleased to have a job which I had been educated for...” (Interviewee 2)

\section{Experiences}

When the experiences are analysed, it can be seen that there have been important breaking points in the historical process. The basic problem of people who entered in the sector in the 1990s and before is finding sources regarding the topic and thus, they face problems when they are becoming experts in the area. Opinions of old generation who participated in the study: "... It is not easy to be one of the first in any field. Resources are restricted. It is hard to be accepted. As a matter of fact, there were 3 books in the literature of Turkish Public Relations. Of course these beginnings of our former professors were precious but I had to contribute to this discipline which needed furthering. I worked hard with this idea. I decided to go to USA in which I had observed planned development with my knowledge, since there were not opportunities like internet. I actualised my plan in 1992..." (Interviewee 9), “... I was doing almost all the works, since public relations was not known completely when I entered the sector. Therefore, I myself could not understand what I was doing for a long time, until I became an executive responsible for corporate communication ..." (Interviewee 11) To satisfy the need of sources, choices of abroad are evaluated. These people returned to their countries enriching the sector and they themselves become a source of information.

Focus of experiences of people who newly-entered the sector has changed. Representatives of the sector from the young generation focus on becoming skilful rather than gender and search of information: "My experiences separate in two points as a person who is new in the sector. The first one is the relationship between me and executives and my colleagues, and the second is my skills in communication technologies. In other words, social media, smart phone applications are affecting professional practices very much. For this reason, I am always facing with the obligation that I should improve myself technically..." (Interviewee 10). This can be considered as a source to develop new hypotheses to determine the position of women within the sector.

\section{Being Woman in the Sector}

When foreign literature is examined, it can be seen that many problems regarding being a woman in the sector have been determined (Childers, 1986; Dozier, chapo\&Sullivan, 1983; Scrimger, 1985; Theus, 1985). However, in studies conducted in Turkey not so many problems about gender have been found (Tany1ldız1, 2011; Körpe, 2014). This proves that sector is directly affected from socio-cultural structure. Participants of the study do not have intense opinions about disadvantages in relation to gender: "I experienced neither advantages nor disadvantages of being woman. In addition, I believe that this situation should be handled by leaving superficial approach and considering it with many other components." (Interviewee 1). Participants, in terms of gender, focused on advantages and disadvantages in relation to the profession's being seen as a woman profession: "Since public relations requires detail, it might be seen as a woman job; however, I think that the strategy behind is more important. Thus, I find such a differentiation incorrect. I think that these relate to personal characteristics and perception of the occupation. Although there are not any research about our country as far as I know, this can be remarked through memberships in occupational organizations: Women are more likely to be interested in this field and outnumber men." (Interviewee 8). It is emphasised that factors regarding women's own nature like being a mother should be considered: "I have never experienced a difficulty in my career because of my gender. Nevertheless, I can say that I am short of time as a working person and who works too hard in the academic world (as a mother). I prefer to sacrifice my sleep for this..." (Interviewee 5) On the other hand, even though some of the participants do not tangibly mention about domination of men, they stated that position of women in the sector should be questioned. "...I do not think that there is a problem about being a woman in the sector but men make up the majority in the executive positions of the company... Sometimes I ask myself: Will I be able to take charge in the top management of this company as an expert of public relations in 20 years time?.." (Interviewee 7)

\section{Ethics and Public Relations}


There have been many studies conducted analysing the relationship between public relations and ethics (Botan, 1997; Kent\&taylor, 2002; Fitzpatrick \& Gauthier, 2001). Almost all the studies mention about the importance of the concept of ethics in public relations. Similarly, participants of the study have focused on the ethics as the basis of public relations and the sector's need of enhancing itself on the topic. "The relationship between ethics and public relations have more importance than any other field because public relations, which is applicable to all the areas, can accelerate consumption or deceive consumer with its effect on marketing communication with a general approach. However, its having a constructive role in the future makes public relations more effective. Public relations has the obligations of being strong and effective, thus it has to be more responsible. In order for us to talk about ethics in public relations, both academicians and sector, and press and institutions should believe in and implement ethic codes together..." (Interviewee 4)

Regarding the topic, with the developments in communication technologies borders of communication has changed and participants, in relation to this, have focused on the need of re-evaluation of the concept of ethics. "...Ethical values did not come to the fore in the first years of the sector all over the world as well as in our country; however, corporations had to protect ethical values due to rapidly spreading information..." (Interviewee 3)

"...Representation of women in the sector and ethical problems... Unfortunately, women are suppressed not only in this sector but also in many others... In addition, the concept of ethic is an important issue that should be re-evaluated with the developments in communication technologies..." (Interviewee 10). Moreno (2013) stated that social media is becoming more popular and thus there are many topics that should be re-evaluated. The basis of these topics is ethics.

\section{Public Relations and Academia}

On account of policies of higher education in Turkey, many universities started to be established beginning from the year 2010. With the beginning of 2016, there are 64 faculties giving lectures on the area of communication (www.yok.gov.tr). This quick growth brings about many problems about the perspective of public relations. "Faculties of communication opened in many universities in 2010 without sufficient quality in our country... I am of the opinion that it is not easy for quality and quantity to be together all the time and this rapid growth of the occupation and the discipline caused them no to be understood completely. It is almost impossible to understand public relations without knowing sociological theories. Academia should be more sensitive. It is required to have the quality to interpret from a holistical viewpoint..." (Interviewee 6)

While the number of women in the academia increases, there are scarcely any feminist factors in the researches (okay\&okay, 2008). This prevents developing hypotheses about the topic and developing a versatile perspective. One of the participants draws attention to this topic: “... A master's thesis about master's theses and doctoral theses in the area of Public Relations which were written between 2003 and 2012 in Turkey is written in 2014. It is highly interesting that there are not any questions about women in the research... Research of feminist values is vital for this sector..." (Interviewee 11)

The basic problem faced during the education of public relations is again related to unbalanced growth in the sector of education. Participants think that insufficient education affects negatively not only the professional life of the person who will practice the profession in the sector but also the development of the profession.

“...Edward Bernays: 'Social responsibility is implementation of public relations. This is the future of America.' What does if public relations is implementation of social responsibility, so this is the future of the country mean? It means public relations builds the future of the country. This occupation is being implemented without understanding this kind of statements, and being taught, which is worse. This is very perilous. I relate this to that: If I am not mistaken by my memory there are about 60 faculties of communication. These faculties are in need of professors immediately. I think acting immediately and building society accordingly without regarding information is very dangerous in this information age. This should be done by professionals. I am of the opinion that academia has deficiency. There are doctoral programs everywhere. This will cause the base of public relations not 
to fit completely in Turkey. For this reason, research of historical development process of public relations in Turkey will be a more important study field in the years to come..." (Interviewee 9)

When doctoral theses are analysed, it is determined that they are more like a continuation of American school rather than producing new models (Seyfi, 2016). Both the area analysis and the opinions of participants showed that there are serious problems regarding academic development.

\section{CONCLUSION}

Position of women in public relations has been discussed in many studies for many years. In particular, Hon (1995) conducted many detailed studies to put forward feminist theory in public relations. There is a huge difference between countries in terms of data collection and resource development about the topic when studies are examined. It is observed that while countries like USA collect extensive and detailed data, developing countries or less developed countries have difficulty in data collection and resource development about the topic. This shows that public relations have a relationship with development levels of countries. In addition, contents of studies about women in public relations have changed in the historical process. For example, while study topics were topics like low salaries and discrimination in the 1980s, recently made studies focus on women's adaption to communication technologies and status.

Within the framework of this study, a sample was created which consists of both the old generation that have been working in this sector for more than 30 years and the rising generation that have just entered this sector in Turkey. Position of women in the occupation of public relations in Turkey was studied through in-depth interviews within this context. Acquired data showed that public relations developed through collective works of men and women. Women are still conducting their studies intensively in practice, in occupational organizations and in academia.

Participants of the research did not mentioned about gender discrimination in the occupation of public relations. Many of them stayed away from sexist statements. Main reason for this is the important positions of the women in the sector who laid the foundation of this occupation in Turkey. People who chose this occupation in the 1960s and 70s were educated and qualified people of the country. In other words, the foundation of this occupation was laid not by chance but by people who willingly chose this sector. Therefore, it could be said that women are not facing with huge problems in getting an executive position in the area of public relations in Turkey. Related studies conducted abroad showed that it is a big problem if women are not promoted to executive positions. Both the occupation and position of women started to be questioned and problems about gender started to increase with the change of method of choosing the occupation and profiles of people who choose the occupation in the historical process in Turkey. This proves that effects of socio-economic factors in the development of the occupation is important.

It can be seen that women contributed to the development of the sector equally with men when the academic development of public relations in Turkey is observed. However, the number of women academicians has increased more in the course of time. Therefore, it can be said that the effects of women in academia has also increased. On the other hand, participants stated that the sector lost its line due to implementation of higher education policies in the country. They also stated that rapidly opened faculties of communication was directed by academic staff consisting of people who did not completely understand this sector, and thus this affected natural development of public relations in a negative way. Research of historical development of the occupation has become more important within this artificial development.

People who are addressed as the doyens of the occupation and have been working in this sector for more than 30 years mentioned about the effects of socio-economic and cultural concepts on change and development of public relations. The rising generation focused on the effects of developments in communication technologies on the sector. Research of position of women in the adaption process of newly arrived communication technology novelties is highly important. It is also highly important that not only qualitative research but also quantitative research should be done for this. Consequently, this 
study should be elaborated, and new studies should be done which include the effects of communication technologies and men.

\section{REFERENCES}

Acar, M (1994). Türk Kamu Yönetiminde Halkla İlişkiler Araştırması, Ankara:Sosyal Planlama Genel Müdürlüğü Planlama Dairesi Başkanlı̆̆.

Al-Jenaibi, B. (2011), "Gender Issues in the Diversity and Practice of Public Relations in the UAE Case Study of P.R. Male Managers and Female P.R. Practitioners", International Journal of EPolitics, Vol. 2 No. 3, pp. 35-56

Asna, M. A. (1988). Halkla İliskilerin Türkiye'de Benimsenmesi. Halkla İlişkiler Sempozyumu-87, Ankara, Ankara Üniversitesi Basın Yayın Yüksekokulu Yayınları, 10, 27-30

Beasley, M. H., \& Theus, K. T. (1988). The New Majority: A look at what the preponderance Of women in journalism education means to the schools and to the professions. Lanham, MD: University Press of America.

Bıçakçı, A. B., Hürmeriç, P. (2013). Milestones in Turkish public relations history. Public Relations Review, 39(2), 91-100.

Botan, C. (1997). Ethics in strategic communication campaigns: The case for a new approach to public relations. Journal of Business Communication, 34(2), 188-202.

Broom, G. M. (1982). A comparison of sex roles in public relations. Public Relations Review.8(3), 1722.

Broom, G. M., Dozier, D, M, (1986). Advancement for public relations role models. Public Relations Review, I2(), 37-56.

Childers, L. L. (1986). Gender and salary: A panel study of public relations practitioners. Unpublished master's thesis. University of Florida, Gainesville.

Ciner, Özgür (2014), Halkla İlişkiler Sektöründe Cinsiyete Dayalı ayrımcılık, Ankara üniversitesi, Sosyal Bilimler Enstitüsü, Halkla İlişkiler Anabilim Dall, Yüksek Lisans Tezi

Dozier, D, M. (1988a). Breaking Public Relations' glass ceiling. Public Relations Review, 14(3), 6-14. Dozier, D. M, Chapo, S, \& Sullivan, B, (1983). Sex And The Bottom Line: Income differences among women and men in public relations. Paper presented at the meeting of the Public Relations Division Erdoğan İ. (2008). Teori ve Pratikte Halkla İliskiler, (2 ed.), Ankara:Pozitif Matbaacıllk.

Eser, A.. (1989). Halkla İliskiler Bir Felsefedir.

Farmer, B. ve Waugh, L. (1999). Gender Differences in Public Relations Students' Career Attitudes: A Benchmark Study. Public Relations Review, 25(2): 235-249.

Faulstich W.(1992). Grundwissen Öffentlichkeitsarbeit Kritische Einführung in Problemder der Public Relations, Bardowick: Wissenschafter Verlag.

Fitzpatrick, K., \& Gauthier, C. (2001). Toward a professional responsibility theory of public relations ethics. Journal of Mass Media Ethics, 16(2-3), 193-212

Franz Ronnenberg F., Rühl M.(1992). Theorie fer Public Relations Ein Entwurf, Opladen:Westdeutscher Verlag, 32

Güler, A., Halıcıoğlu M. B., and Taşğın, S. (2013). Sosyal Bilimlerde Nitel Araştırma Yöntemleri. Ankara: Seçkin Yayınları.

Gürel, T. (2006). Halkla İlişkiler Profesyonelleri, İletişim Fakülteleri Mezunlarında Neler Arıyorlar: Ajans Yöneticilerinin Bakış Açıları. Kocaeli Üniversitesi, II. Ulusal Halkla İlişkiler Sempozyumu, 2728.

Grunig, L. A., Toth, E. L., \& Hon, L. C. (2000). Feminist Values In Public Relations. Journal of Public Relations Research, 12(1), 49-68.

Harlow, R. (1977). Public Relations Definitions Through the Years, Public Relations Review 3 (1):4963

Hızal, G. S. G., Özdemir, B. P., \& Yamanoğlu, M. A. (2014). Tracking Public Relations History in 1960s' Turkey: The prevalence and reflections of development discourse. Public Relations Review, 40(4), 632-638.

Hon, L. C. (1995). Toward a Feminist Theory of Public Relations. Journal of Public Relations Research, 7(1), 27-88

İşler, E., Keloğlu İ. (2010). Ulusal Bilincin İnşası Sürecinde Halkla İlişkiler”, Cumhuriyet Döneminde Iletisim Kurumlar, Politikalar, Der. Nazife Güngör, Ankara. 
Gower, K. (2008). US Corporate Public Relations in the Progressive Era. Journal of communication management .12 (4):305-318.

Kazancı M. (2006). Osmanlı da Halkla İliş̧kiler, Selçuk İletiş̧im Dergisi , 4 (3):5-20

Kazancl, M. (1997). Kamuda ve Özel Sektörde Halkla Illişkiler. Ankara: Turhan Kitabevi.

Kent, M. L., \& Taylor, M. (2002). Toward a dialogic theory of public relations. Public relations review, 28(1), 21-37.

Makovsky, K. (2013). Women in Leadership in PR. Retrieved from http://www.forbes.com/sites/kenmakovsky/2013/02/25/davos-blog-1-women-in-leadership-in-pr/

Moreno, M. A., Goniu, N., Moreno, P. S., \& Diekema, D. (2013). Ethics of social media research: Common concerns and practical considerations. Cyberpsychology, Behavior, and Social Networking, 16(9), 708-713.

Öksüz, B., Görpe, S. (2014). Türklye'de halkla ılıskıler alanında kadının yerı: akademisyenler, uygulamacılar ve meslek örgütü temsilcılerının konuya yaklasımları. Istanbul Üniversitesi İletisim Fakültesi Dergisi, (47), 125-142.

Keating, M. (2007). Feminine Roles in the Ottoman Empire: The Significance of Women during the Sultanate of Women Period. Women.

Küpeli, Ö. (2015). Kösem Sultan'a Ait Bir Muhallefât Kaydı. Cihannüma: Tarih ve Coğrafya Araştırmaları Dergisi, 1(2), 131-143.

Okay, A.\& Okay, A. (2014). Halkla İlişkiler Kavram Stratejileri ve Uygulamaları. İstanbul: Der Yayinlart.

Okay, A., \& Okay, A. (2008). Undergraduate and graduate public relations education in Turkey: A quantitative study of dissertations contributions to public relations field (1984-2007). Selçuk Iletişsim Dergisi, Ocak, 5-14.

Scrimger, J. (1989). Women communicators in Canada: A case for optimism, In E. L. Toth, CTheus, K. T. (1985). Gender shifts in journalism and public relations. Public Relations Review, 11(1), 42-50.

Seidman, I. (2013). Interviewing As Qualitative Research: A guide for researchers in education and the social sciences. Teachers college press.

Seyfi, M. (2016). A Content Analysis of Turkish Doctoral Dissertations in Public Relations. Erciyes İletişim Dergisi, 4(4).

Şanl, H. K. (2015). The Historiography of Public Relations in Turkish Public Relations Books. Galatasaray Üniversitesi Illeti-ş-im Dergisi, (23), 135-149.

Tanylldızı, N. I. (2011). Türkiye'de Halkla İlişkiler Mesleğinde Kadın.Karamanoğlu Mehmetbey Üniversitesi Sosyal ve Ekonomik Araştırmalar Dergisi, (1), 75-81.

Tanylldızı, N. İ. (2011). Türkiye'de Halkla İlişkiler Mesleğinde Kadın. KMÜ Sosyal ve Ekonomik Araştırmalar Dergisi, 13 (20), 75-81.

Turan K. (2014). Halkla ilișkiler eğitimi gören üniversite öğrencilerinin kadınların halkla ilişkiler alanında yönetici olmalarına ilişkin tutumları: cinsiyet ve cinsiyet rolü yöneliminin etkileri, Başkent üniversitesi, Halkla İlişkiler ve Tanıtım Bölümü, Master Thesis.

Turk. J, V. (1986). The shifting salary scene. Currents. 72(6). 20.

Uysal, sezer, http://remas-net.blogspot.com.tr/2013/10/turkiyede-kadin-istihdami-halkla.html

Yamanoğlu M. A., Lamme, M.O., v.d (2009), The state of Public Relations History." Amerikan Journalism 26 (1):156-159

Yavuz, Ş. (2008). Türk Halkla Ilişkiler Tarihinden Gizli Kalmış Bir Sayfa: Ziraat Bankası Beşikdüzü Şubesi ve Sila Dergisi. Galatasaray University Journal of Communicationi, 8(8).

Yaxley, H. M. L. (2013), "Career experiences of women in British public relations (1970-1989)", Public Relations Review, Vol. 39, pp. 156-165.

Ylldırım, D., Metin, S. (2006). Halkla ilişkiler ve cinsiyet. ll. ulusal halkla ilişkiler sempozyumu, Kocaeli Üniversitesi İletişim Fakültesi Dergisi, 45-50.

Zerfass, A., Tensch, R., Vercic, D., Verhoeven, P. \& Moreno, A. (2014). European Communication Monitor 2014. Excellence in Strategic Communication-Key Issues, Leadership, Gender and Mobile Media. Results of A Survey in 42 Countries. Brussels: EACD/EUPRERA, Helios Media 